Volume 10, Nomor 1, Mei 2018, pp 85-97 Copyright (C) 2017 Jurnal Akuntansi Maranatha, Program Studi Akuntansi, Fakultas Ekonomi, Universitas Kristen Maranatha. ISSN 2085-8698 | e-ISSN 2598-4977. http://journal.maranatha.edu

\title{
Analisis Tingkat Kesehatan Bank Dengan Menggunakan Metode Risk-Based Bank Rating (RBBR) (Studi Pada Bank yang Termasuk Saham LQ45 Sub Sektor Perbankan Tahun 2010-2016)
}

\author{
Bobby Wijaya \\ Program Studi Magister Manajemen-Univ. Katolik Parahyangan \\ (Jl. Merdeka No. 30, Bandung) \\ fransiskusbobby@gmail.com
}

\begin{abstract}
This paper seeks to find out the health level of banks in Indonesia Stock Exchange LQ45 Index. It used descriptive methods with qualitative approach that is Risk Based Bank Rating $(R B B R)$ model. RBBR model consists of 4 factors among others: risk profile, good corporate governance (GCG), earnings and capital factor.The analytical tool used in this study is the assessment of the level of health of banks in Indonesia Stock Exchange LQ45 Index against the risk factor using the ratio of net performing loans (NPLS) and Loan to Deposit Ratio $(L D R)$, a factor of corporate governance by using the self-assessment report of good corporate governance, the earnings factor using the ratio of return on assets (ROA) and net interest margin (NIM) and the factor of capital using the ratio of capital adequacy ratio $(C A R)$. The results showed that there are several banks which have "Less Healthy", "Healthy Enough", "Pretty Good". Bank Mandiri, BRI and BNI received the predicate of "Pretty Good" in risk profile factor for liquidity risk, whereas Bank BTN received the predicate of "Healthy Enough". Also, Bank BTN received the predicate of "Healthy Enough" and "Pretty Good" in earnings factor specifically ROA and GCG factor.
\end{abstract}

Keywords: Indonesia Stock Exchange LQ45 Index, Health Level of Banks, Risk Based Bank Rating (RBBR) Model.

\section{Pendahuluan}

Sektor perbankan merupakan salah satu sektor yang kegiatan operasionalnya cukup dijaga ketat oleh pemerintah. Hal tersebut dilakukan karena perbankan memiliki peran penting dalam kehidupan masyarakat di suatu negara. Beberapa fungsi perbankan yang sangat dikenal oleh seluruh lapisan masyarakat adalah fungsi perbankan sebagai penghimpun dana dan penyalur dana atas kebutuhan-kebutuhan yang ada di 
masyarakat. Selain itu, fungsi perbankan yang tidak kalah penting adalah mengelola dana yang sudah terhimpun dari masyarakat atau disebut juga dana pihak ketiga. Dana pihak ketiga (DPK) adalah salah satu sumber kas masuk perbankan yang digunakan untuk menjalankan aktivitas operasional perbankan. Sebagian besar dana kelolaan perbankan adalah DPK. Perbankan sangat diatur oleh pemerintah dikarenakan apabila perbankan salah mengelola dana tersebut, maka banyak sekali masyarakat yang akan dirugikan atau dengan kata lain menyangkut hidup banyak orang.

Risiko sistemik dapat digambarkan sebagai situasi di mana ketidakstabilan atau runtuhnya seluruh industri atau ekonomi yang disebabkan karena adanya kegagalan besar dalam mengelola risiko oleh satu atau beberapa perusahaan. Pada tahun 2008, risiko sistemik pernah terjadi dan mengganggu kestabilan dunia. Risiko sistemik tersebut terjadi karena bangkrutnya salah satu bank investasi terbesar di dunia yaitu Lehman Brothers. Keadaan tersebut memicu ketidakstabilan perbankan lain dikarenakan banyak bank lain yang memiliki investasi pada Lehman Brothers sehingga kejadian tersebut menimbulkan efek contagion $^{l}$ terhadap perbankan lain di dunia.

Untuk menjaga stabilitas perbankan, banyak regulasi yang sudah dibuat sedemikian rupa agar perbankan lebih tahan terhadap guncangan-guncangan seperti krisis atau risiko sistemik. Salah satu upaya menjaga stabilitas perbankan agar dapat mengurangi baik kemungkinan terjadinya maupun dampak dari suatu krisis adalah dengan cara menjaga kesehatan perbankan itu sendiri. Kesehatan bank dapat didefinisikan sebagai kemampuan suatu bank beroperasi secara normal serta mampu memenuhi semua kewajibannya dengan

${ }^{1}$ Contagion adalah penyebaran gangguan berupa perubahan ekstrim harga pasar dari satu pasar regional ke pasar lainnya. baik sesuai dengan peraturan-peraturan yang berlaku.

Kebijakan mengenai kesehatan bank sudah lama diatur. Pada tahun 2011, kebijakan mengenai penilaian tingkat kesehatan bank diperbaharui kembali oleh Bank Indonesia dengan menerbitkan Peraturan Bank Indonesia No. 13/PBI/2011. Pada peraturan tersebut, perbankan diminta untuk menggunakan metode RBBR (riskbased bank rating) untuk menilai tingkat kesehatan bank. Metode tersebut merupakan metode penyempurnaan dari metode CAMELS (Capital Adequacy, Assets Quality, Management, Earning, Liquidity dan Sensitivity). Metode RBBR terdiri dari empat komponen, antara lain: Risk Profile, Good Corporate Governance (GCG), Earning, dan Capital. Dalam kasus ini, peneliti hendak menganalisis tingkat kesehatan perbankan yang termasuk saham LQ45 di Indonesia dengan menggunakan metode RBBR pada tahun 2010-2016.

\section{Rumusan Masalah}

Pentingnya industri perbankan bagi stabilitas dan perekonomian suatu negara menjadikan industri perbankan sangat diatur. Besarnya biaya pemulihan (recovery cost) ketika terjadi krisis di industri tersebut, runtuhnya industri-industri lain akibat krisis industri perbankan dan rusaknya stabilitas ekonomi suatu negara merupakan beberapa contoh dampak yang dihasilkan apabila sistem perbankan tidak berjalan sebagai mana mestinya.

Krisis keuangan global tahun 2008 merupakan kejadian yang telah menyebabkan perlambatan ekonomi Amerika yang selanjutnya memicu perlambatan ekonomi dunia. Krisis tersebut bermula dari jatuhnya kredit-kredit pada industri properti yang disalurkan oleh perbankan di Amerika Serikat yang selanjutnya menimbulkan krisis keuangan tidak hanya perbankan saja melainkan juga industri lain. Dari kejadian tersebut, Lehman Brothers, salah satu Bank investasi terbesar, dinyatakan bankrut yang 
menyebabkan perusahaan-perusahaan lain juga bankrut.

Penelitian ini bertujuan untuk mengetahui sampai sejauh mana tingkat kesehatan perbankan di Indonesia yang termasuk saham LQ45 pada tahun 20102016. Dengan mengetahui tingkat kesehatan suatu perbankan, maka diharapkan penelitian ini dapat berguna dalam pengambilan keputusan investasi.

\section{Kerangka Teoritis dan Hipotesis}

\section{Bank}

Bank menurut UU No. 10 Tahun 1998 Tentang Perbankan didefinisikan sebagai "Badan usaha yang menghimpun dana dari masyarakat dalam bentuk kredit dan atau bentuk-bentuk lainya dalam rangka meningkatkan taraf hidup orang banyak. Sementara itu, Perbankan didefinisikan sebagai "segala sesuatu yang menyangkut tentang bank, mencakup kelembagaan, kegiatan usaha, serta cara dan proses dalam melaksanakan kegiatan usahanya".

\section{Laporan Keuangan}

Menurut Sundjaja, Ridwan S., Inge B., dan Dharma P.S., 2013:115, laporan keuangan adalah suatu laporan yang menggambarkan hasil dari proses akuntansi yang digunakan sebagai alat komunikasi antar data keuangan atau aktivitas perusahaan dengan pihak-pihak yang berkepentingan dengan data atau aktivitas tersebut. Laporan keuangan bertujuan untuk menyediakan informasi yang menyangkut posisi keuangan, kinerja, serta perubahan posisi keuangan suatu perusahaan yang bermanfaat bagi sejumlah besar pemakai laporan keuangan dalam pengambilan putusan secara ekonomi.

\section{Tingkat Kesehatan Bank}

Menurut POJK No. 3 Tahun 2016 Tentang Penilaian Tingkat Kesehatan Bank Umum, tingkat kesehatan bank adalah hasil penilaian kondisi Bank yang dilakukan terhadap risiko dan kinerja Bank. Penilaian tingkat kesehatan bank diukur dengan menggunakan pendekatan Risk-based Bank Rating (RBBR) melalui suatu peringkat komposit terhadap faktor-faktor penilaian yang ada di pendekatan RBBR.

\section{Risk-based Bank Rating (RBBR)}

Sesuai dengan POJK No. 3 Tahun 2016 Tentang Penilaian Tingkat Kesehatan Bank Umum, bank wajib memelihara dan/atau meningkatkan Tingkat Kesehatan Bank dengan menerapkan prinsip kehati-hatian dan manajemen risiko dalam melaksanakan kegiatan usaha. Untuk melakukan penilaian Tingkat Kesehatan Bank dengan menggunakan pendekatan risiko (Riskbased Bank Rating) baik secara individu maupun secara konsolidasi dengan cakupan penilaian terhadap profil risiko (risk profile) ,Good Corporate Governance (GCG), rentabilitas (earnings), dan permodalan (capital).

\section{Profil Risiko}

Menurut POJK No. 3 Tahun 2016 Tentang Penilaian Tingkat Kesehatan Bank Umum, penilaian terhadap profil risiko merupakan penilian terhadap risiko inheren dan kualitas penerapan manajemen risiko dalam operasional Bank yang wajib dilakukan terhadap 8 (delapan) risiko, yaitu: risiko kredit, risiko pasar, risiko likuiditas, risiko operasional, risiko hukum, risiko stratejik, risiko kepatuhan, dan risiko reputasi. Namun dalam penelitian ini, penulis hanya menggunakan penilaian terhadap risiko kredit dan risiko likuiditas yang diwakili oleh rasio Non-Performing Loan (NPL) sebagai risiko kredit dan Loan to Deposit Ratio (LDR) sebagai risiko likuiditas. 
Tabel 1

Predikat Kesehatan Bank Berdasarkan NPL

\begin{tabular}{|l|l|l|}
\hline No & \multicolumn{1}{|c|}{ Rasio } & \multicolumn{1}{|c|}{ Predikat } \\
\hline 1 & $0 \%<$ NPL $<2 \%$ & Sangat Sehat \\
\hline 2 & $2 \% \leq \mathrm{NPL}<5 \%$ & Sehat \\
\hline 3 & $5 \% \leq \mathrm{NPL}<8 \%$ & Cukup Sehat \\
\hline 4 & $8 \% \leq \mathrm{NPL}<12 \%$ & Kurang Sehat \\
\hline 5 & NPL $\geq 12 \%$ & Tidak Sehat \\
\hline
\end{tabular}

Sumber: Surat Edaran Bank Indonesia

No.13/ 24/ DPNP tahun 2011

Tabel 2

Predikat Kesehatan Bank Berdasarkan LDR

\begin{tabular}{|c|c|c|}
\hline No & Rasio & Predikat \\
\hline 1 & $50 \%<\mathrm{LDR} \leq 75 \%$ & Sangat Sehat \\
\hline 2 & $75 \%<\mathrm{LDR} \leq 85 \%$ & Sehat \\
\hline 3 & $85 \%<\mathrm{LDR} \leq 100 \%$ & Cukup Sehat \\
\hline 4 & $\begin{array}{l}100 \%<\mathrm{LDR} \leq \\
120 \%\end{array}$ & $\begin{array}{l}\text { Kurang } \\
\text { Sehat }\end{array}$ \\
\hline 5 & LDR > $120 \%$ & Tidak Sehat \\
\hline
\end{tabular}

Sumber: Surat Edaran Bank Indonesia No.6/ 23/ DPNP tahun 2004

\section{GCG}

Menurut POJK No. 3 Tahun 2016 Tentang Penilaian Tingkat Kesehatan Bank Umum, penilaian terhadap faktor GCG merupakan penilaian terhadap manajemen Bank atas pelaksanaan prinsip-prinsip GCG.
Tabel 3

Peringkat Komposit GCG

\begin{tabular}{||l|c|l|}
\hline No & \multicolumn{1}{|c|}{ Rasio } & Predikat \\
\hline 1 & Nilai Komposit $<1,5$ & Sangat Baik \\
\hline 2 & $1,5<$ Nilai Komposit $<2,5$ & Baik \\
\hline 3 & $2,5<$ Nilai Komposit $<3,5$ & Cukup Baik \\
\hline 4 & $3,5<$ Nilai Komposit $<4,5$ & Kurang Baik \\
\hline 5 & \begin{tabular}{c} 
Nilai Komposit $>4,5$ \\
\multicolumn{3}{|c|}{ Sumber: Surat Edaran Bank Indonesia } \\
No.6/ 23/ DPNP tahun 2004
\end{tabular} \\
\hline \multicolumn{3}{|c|}{ Tidak Baik } \\
\hline
\end{tabular}

\section{Rentabilitas}

Menurut POJK No. 3 Tahun 2016 Tentang Penilaian Tingkat Kesehatan Bank Umum, penilaian terhadap faktor rentabilitas (earnings) meliputi penilaian terhadap kinerja rentabilitas (earnings), sumbersumber rentabilitas (earnings), dan kesinambungan rentabilitas (earnings' sustainability) Bank. Dalam penelitian ini, peneliti menggunakan rasio Return on Assets (ROA) dan Net Interest Margin (NIM) sebagai rasio yang menggambarkan kinerja rentabilitas suatu bank.

\section{Tabel 4}

Predikat Kesehatan Bank Berdasarkan ROA

\begin{tabular}{|l|l|l|}
\hline No & \multicolumn{1}{|c|}{ Rasio } & \multicolumn{1}{|c|}{ Predikat } \\
\hline 1 & $1,5 \%<\mathrm{ROA}$ & Sangat Sehat \\
\hline 2 & $1,25 \%<\mathrm{ROA} \leq 1,5 \%$ & Sehat \\
\hline 3 & $0,5 \%<\mathrm{ROA} \leq 1,25 \%$ & Cukup Sehat \\
\hline 4 & $\begin{array}{l}0 \%<\mathrm{ROA} \leq 0,5 \% \\
\text { Kurang } \\
\text { Sehat }\end{array}$ \\
\hline 5 & $\begin{array}{l}\text { ROA } \leq \quad 0 \% \quad \text { atau } \\
\text { negatif })\end{array}$ & Tidak Sehat \\
\hline
\end{tabular}

Sumber: Surat Edaran Bank Indonesia No.13/ 24/ DPNP tahun 2011 
Tabel 5

Predikat Kesehatan Bank Berdasarkan NIM

\begin{tabular}{|l|l|l|}
\hline No & \multicolumn{1}{|c|}{ Rasio } & \multicolumn{1}{|c|}{ Predikat } \\
\hline 1 & $3 \%<$ NIM & Sangat Sehat \\
\hline 2 & $2 \%<$ NIM $\leq 3 \%$ & Sehat \\
\hline 3 & $\begin{array}{l}1,5 \%<\text { NIM } \leq \\
2 \%\end{array}$ & Cukup Sehat \\
\hline 4 & $\begin{array}{l}1 \%<\text { NIM } \leq \\
1,5 \%\end{array}$ & $\begin{array}{l}\text { Kurang } \\
\text { Sehat }\end{array}$ \\
\hline 5 & NIM $\leq 1 \%$ & Tidak Sehat \\
\hline
\end{tabular}

Sumber: Surat Edaran Bank Indonesia No. 6/ 23/ DPNP tahun 2004

\section{Permodalan}

Menurut POJK No. 3 Tahun 2016 Tentang Penilaian Tingkat Kesehatan Bank Umum, penilaian terhadap faktor permodalan (capital) meliputi penilaian terhadap tingkat kecukupan permodalan dan pengelolaan permodalan.

\section{Tabel 6}

Predikat Kesehatan Bank Berdasarkan CAR

\begin{tabular}{|l|l|l|}
\hline No & \multicolumn{1}{|c|}{ Rasio } & \multicolumn{1}{|c|}{ Predikat } \\
\hline 1 & $12 \%<$ CAR & Sangat Sehat \\
\hline 2 & $\begin{array}{l}9 \% \leq \mathrm{CAR}< \\
12 \%\end{array}$ & Sehat \\
\hline 3 & $8 \% \leq \mathrm{CAR}<9 \%$ & Cukup Sehat \\
\hline 4 & $6 \%<\mathrm{CAR}<8 \%$ & $\begin{array}{l}\text { Kurang } \\
\text { Sehat }\end{array}$ \\
\hline 5 & CAR $\leq 6 \%$ & Tidak Sehat \\
\hline
\end{tabular}

Sumber: Surat Edaran Bank Indonesia No.13/ 24/ DPNP tahun 2011

\section{Metode Penelitian}

\section{Penentuan Populasi dan Sampel}

Populasi dipilih sampel dengan menggunakan teknik purposive sampling. Dari teknik tersebut diperoleh 5 Bank yang menjadi penelitian. Dalam penelitian ini, untuk menentukan sampel digunakan kriteria-kriteria sebagai berikut:

1. Bank Umum terdaftar di Bursa Efek Indonesia bersifat konvensional yang beroperasi di Indonesia tahun 2010-2016.

2. Bank Umum termasuk dalam ketegori indeks LQ45 per tahun 2016.

3. Bank yang memiliki data laporan tahunan lengkap dengan rasio keuangan seperti NPL, LDR, ROA, NIM, CAR dan laporan pelaksanaan hasil self-assessment Good Coorporate Governance tahun 2010-2016.

\section{Sumber Data}

Dalam mengumpulkan data yang diperlukan, peneliti menggunakan data sekunder yaitu Laporan Tahunan (Annual Report) setiap bank pada tahun 2010-2016.

\section{Teknik Pengumpulan Data}

Penelitian ini menggunakan teknik studi dokumentasi untuk memperoleh data sekunder yang dibutuhkan. Data tersebut diperoleh dari website resmi setiap bank dan Bursa Efek Indonesia (BEI).

\section{Analisis Data}

1. Menilai tingkat kesehatan perbankan dengan metode Risk Based Bank Rating (RBBR) tahun 2010-2016.

2. Menganalisis perbandingan tingkat kesehatan perbankan dengan metode deskriptif kuantitatif Risk Based Bank Rating (RBBR) tahun 2010 - 2016. 


\section{Hasil Penelitian dan Pembahasan}

\section{Analisis Profil Risiko}

\section{Risiko Kredit (Non-Performing Loan- NPL)}

Risiko kredit merupakan risiko terbesar dalam sistem perbankan di Indonesia serta dapat menjadi penyebab utama bankrutnya suatu bank. Salah satu alat ukur risiko kredit dalam profil risiko suatu bank adalah rasio kredit bermasalah atau NPL. Rasio NPL mencerminkan seberapa besar tingkat gagal bayar yang ditanggung oleh bank dalam suatu periode tertentu. Bank saat ini diatur oleh OJK agar dapat mempertahankan rasio NPL di bawah angka 5\%. NPL yang berada di bawah angka 5\% menggambarkan bahwa suatu bank masih dikategorikan sebagai bank yang sehat dalam hal pengelolaan atau penanganan risiko kredit. Di samping itu, pada tahun 2016 perbankan nasional menunjukkan rasio NPL yang berkisar 2,93\%. Hal tersebut menunjukkan bahwa perbankan dengan rasio NPL yang berada di bawah 2,93\% memiliki performa yang baik.

Dalam penelitian ini, seluruh bank yang termasuk saham LQ45 memiliki NPL yang berada di bawah 5\%. Dengan kata lain, bank-bank yang diteliti oleh peneliti memiliki predikat "Sehat" atau bahkan beberapa memiliki predikat "Sangat Sehat". Tabel 7 menunjukkan profil risiko kredit dari kelima bank yang diteliti. Predikat "Sangat Sehat" hanya diperoleh oleh Bank BCA dari tahun 2010 hingga 2016. Di sisi lain, mengacu pada rata-rata NPL perbankan nasional pada tahun yaitu sebesar 2,90\%, Bank Mandiri dan BNI tercatat memiliki NPL melebihi rata-rata perbankan nasional yaitu masing-masing sebesar 3,96\% dan 3,00\%, namun dengan angka tersebut, bank masih dapat dikategorikan sebagai bank yang sehat. Lebih lanjut, Bank BNI dan BTN tidak memperoleh predikat "Sangat Sehat" dalam periode penelitian.

\section{Risiko Likuiditas (Loan to Deposit Ratio- LDR)}

Loan to Deposits Ratio merupakan rasio yang mengukur likuiditas suatu bank terhadap kewajiban jangka pendeknya. Pengertian lainnya, LDR merupakan rasio yang membandingkan total kredit yang disalurkan dengan jumlah penerimaan dana dari berbagai sumber. LDR suatu bank yang terlalu rendah menggambarkan bahwa suatu bank memiliki likuiditas yang tinggi namun di sisi lain pendapatannya mungkin lebih rendah. Implikasi lain dari rendahnya LDR adalah kurang efektifnya penggunaan dana pihak ketiga oleh suatu bank yang menyebabkan dana pihak ketiga tersebut "menganggur" dan hanya menunggu dan akan disalurkan apabila ada pinjaman yang diajukan. Sebaliknya, LDR suatu bank yang terlalu tinggi menggambarkan bahwa suatu bank memiliki likuiditas yang sangat rendah namun mungkin saja memiliki profitabilitas yang lebih tinggi. Tingginya LDR suatu bank juga menggambarkan bahwa suatu bank terlalu banyak menyalurkan kredit sehinggan melampaui batas maksimum dana yang dimiliki oleh suatu bank. Bank dapat dikatakan memiliki LDR yang "Sehat" apabila memiliki LDR 75 hingga $85 \%$.

Tabel 8 menunjukkan profil risiko likuiditas yang diwakili oleh variabel LDR dari kelima bank yang diteliti. Bank BCA memiliki LDR dengan nilai terendah sebesar $55,2 \%$ pada tahun 2010 dan nilai tertinggi sebesar 81,1\% pada tahun 2015 . Pada tahun 2010 hingga 2012, dapat dikatakan bahwa Bank BCA memiliki rasio LDR yang sangat rendah yaitu berada di bawah angka $69 \%$. Hal ini mencerminkan Bank BCA pada posisi over liquid pada tahun 2010 hingga 2012. Di samping itu, rata-rata LDR tertinggi dimiliki oleh Bank BTN yaitu pada tahun 2014 sebesar $108,78 \%$. Bank BTN memiliki rata-rata LDR sebesar $105,2 \%$ yang bepredikat "Kurang Sehat" selama periode penelitian berlangsung. Hal ini menunjukkan bahwa 
Bank BTN berada pada posisi over lending dari tahun 2010 hingga 2016.

\section{Analisis Good Corporate Governance (GCG)}

Pelaksanaan GCG saat ini telah menjadi perhatian dan tolak ukur para pemangku kepentingan dalam hal melihat kestabilan serta keberlanjutan suatu bank. Kestabilan dan keberlanjutan suatu bank salah satunya dapat tercermin melalui kualitas manajemen yang ada di dalam suatu bank. Oleh karena itu, dalam metode RBBR untuk menilai kesehatan suatu bank, penilaian terhadap GCG pun turut dilakukan. Penilaian terhadap GCG pada metode RBBR menilai manajemen di suatu bank melalui penerapan atau pelaksanaan prinsip-prinsip GCG. Penilaian terhadap penerapan atau pelaksanaan prinsip-prinsip GCG dikategorikan menjadi 5 predikat, antara lain: "Sangat Baik", "Baik", "Cukup Baik", "Kurang Baik", dan "Tidak Baik". Penilian GCG dapat dilihat pada tabel 9.

Bank yang memiliki predikat "Sangat Baik" selama periode penelitian (2010 hingga 2016) adalah Bank BCA. Selanjutnya Bank BTN, Bank BTN memperoleh predikat "Sangat Baik" pada tahun 2010 hingga 2012, predikat "Baik" pada tahun 2014 hingga 2016, dan predikat "Cukup Baik" pada tahun 2013. Sementara itu, bank-bank lainnya seperti Bank BRI, Mandiri, dan BNI memiliki predikat "Sangat Baik" dan juga "Baik" selama periode penelitian ini dilakukan.

\section{Analisis Rentabilitas}

\section{Return on Assets (ROA)}

ROA merupakan salah satu rasio untuk menghitung seberapa efektif suatu bank menggunakan asetnya dalam menghasilkan keuntungan. Nilai ROA yang semakin besar menunjukan keuntungan yang lebih besar dan menggambarkan bahwa performa suatu bank pada posisi yang sangat baik. Bank yang memiliki ROA di atas $2 \%$ sudah dianggap "Sangat Sehat". Di sisi lain, rata- rata ROA Bank Umum per 2016 yang tercatat sebesar 2,23\%, apabila suatu bank dapat menghasilkan ROA di atas 2,23\%, bank tersebut dapat dikatakan bank yang berperforma baik.

Hampir seluruh ROA perbankan yang diteliti memperoleh predikat "Sangat Sehat", namun pada tahun 2014, Bank BTN memperoleh predikat "Cukup Sehat" dengan ROA sebesar 1,14\% (lihat tabel 10). Rata-rata ROA selama periode penelitian adalah Bank BCA $(3,77 \%)$, BRI $(4,64 \%)$, Mandiri (3,25\%), dan BNI (2,93\%), sedangkan Bank BTN membukukan ROA sebesar $1,76 \%$. Dilihat dari data yang sudah diolah, Bank BRI merupakan Bank dengan rata-rata ROA yang tertinggi yaitu $4,64 \%$. Bank BRI memiliki ROA terendah pada tahun 2016 yaitu 3,84\% dan ROA tertinggi pada tahun 2012 yaitu 5,15\%. Sementara itu, Bank BTN memiliki rata-rata ROA yang terendah sebesar $1,76 \%$ dengan ROA terendah pada tahun 2014 yaitu 1,14\% dan ROA tertinggi pada tahun 2010 sebesar $2,05 \%$.

Rasio ROA salah satunya dapat terimplikasi oleh rasio LDR, hanya saja hasilnya tidak mutlak. Pada umumnya, rasio LDR yang tinggi mencerminkan ROA yang tinggi pula. Hal tersebut dimungkinkan karena dengan menyebarkan banyak kredit kepada debitur. Namun perlu diperhatikan pula bahwa menyebarkan banyak kredit tidak selalu memberikan pendapatan yang tinggi, ada kemungkinan bahwa NPL atau tingkat gagal bayar juga meningkat yang membuat pendapatan kita menurun. Rasio LDR yang tinggi diikuti oleh ROA yang tinggi pula dialami oleh Bank BRI. Dengan rata-rata LDR sebesar $82,29 \%$ menghasilkan rata-rata ROA sebesar 4,64\%. Namun, LDR yang tinggi tapi tidak menghasilkan ROA yang tinggi pula dirasakan oleh Bank BTN. Bank BTN memiliki rata-rata LDR sebesar 105,20\% namun hanya membukukan ROA sebesar $1,75 \%$. 


\section{Net Interest Margin (NIM)}

Rasio NIM merupakan rasio yang menunjukkan perbandingan antara pendapatan bunga bersih/net interest income (NII) dengan rata-rata aset produktif. Apabila nilai dari NIM suatu perbankan tinggi, maka hal tersebut menunjukkan bahwa perbankan tersebut efektif dalam mengelola aset produktifnya. Di sisi lain, tingginya NIM memiliki dampak negatif pada persaingan dengan perbankan negara-negara tetangga (ASEAN). Indonesia saat ini dinilai memiliki margin yang terlalu tinggi sehingga kalah bersaing dengan perbankan negara-negara tetangga. Sebagai perbandingan, NIM perbankan di Thailand berkisar 3\%-4\% pada tahun 2016.

Pada penelitian ini, seluruh perbankan yang diteliti terkait dengan rasio NIM memperoleh predikat "Sangat Sehat". Hal tersebut dapat dilihat pada tabel 11. NIM tertinggi dimiliki oleh Bank BRI yaitu $8,89 \%$ secara rata-rata selama tahun 2010 hingga 2016. Bank BRI memiliki rasio NIM tertinggi pada tahun 2010 sebesar $10,77 \%$ dan terendah pada tahun 2015 sebesar 8,13\%. Rata-rata rasio NIM terendah dimiliki oleh Bank BTN dengan nilai sebesar 5,33\%. Rasio NIM tertinggi dan terendah yang diperoleh oleh Bank BTN adalah 5,99\% dan 4,47\%.
Tabel 7

Analisis Profil Risiko Risiko Kredit (Non-Performing Loan-NPL)

\begin{tabular}{|c|c|c|c|c|c|c|}
\hline No. & $\begin{array}{l}\text { Rode } \\
\text { Sabam }\end{array}$ & $\begin{array}{c}\text { Nama } \\
\text { Percabasa }\end{array}$ & Tahro & NPL & $\begin{array}{c}\text { Indelss } \\
\text { Komposit }\end{array}$ & Predicat \\
\hline \multirow{7}{*}{1} & \multirow{7}{*}{$B B C A$} & \multirow{7}{*}{$\begin{array}{l}\text { Bank } \\
\text { Ceatral } \\
\text { Asia }\end{array}$} & 2010 & $0,60 \%$ & 1 & Sanzat Sebst \\
\hline & & & 2011 & $0,50 \%$ & 1 & Sanzat Sebat \\
\hline & & & 2012 & $0,40 \%$ & 1 & Sanzat Sabat \\
\hline & & & 2013 & $0,40 \%$ & 1 & Sanzat Sebat \\
\hline & & & 2014 & $0,60 \%$ & 1 & Sanzat Sebat \\
\hline & & & 2015 & $0,70 \%$ & 1 & Sanzat Sthat \\
\hline & & & 2016 & $1,30 \%$ & 1 & Sunzat Stbat \\
\hline \multirow{7}{*}{2} & \multirow{7}{*}{ BBRI } & \multirow{7}{*}{$\begin{array}{c}\text { Bank } \\
\text { Rafyat } \\
\text { Indooesia }\end{array}$} & 2010 & $2,75 \%$ & 2 & Sebat \\
\hline & & & 2011 & $2,30 \%$ & 2 & Sthat \\
\hline & & & 2012 & $1,73 \%$ & 1 & Sanzat Sebat \\
\hline & & & 2013 & $1,35 \%$ & 1 & Sanzat Sebat \\
\hline & & & 2014 & $1,69 \%$ & 1 & Sanzat Sehat \\
\hline & & & 2015 & $2,0 \%$ & 2 & Sebat \\
\hline & & & 2016 & $2,05 \%$ & 2 & Stbat \\
\hline \multirow{7}{*}{3} & \multirow{7}{*}{ BMRI } & \multirow{7}{*}{$\begin{array}{c}\text { Bank } \\
\text { Mandiri }\end{array}$} & 2010 & $2,21 \%$ & 2 & Stbat \\
\hline & & & 2011 & $2,13 \%$ & 2 & Selat \\
\hline & & & 2012 & $1,74 \%$ & 1 & Sanzat Sebat \\
\hline & & & 2013 & $1,60 \%$ & 1 & Sanzat Sabat \\
\hline & & & 2014 & $1,66 \%$ & 1 & Sanzat Sthat \\
\hline & & & 2015 & $2,29 \%$ & 2 & Sebst \\
\hline & & & 2016 & $3,95 \%$ & 2 & Sthat \\
\hline \multirow{7}{*}{4} & \multirow{7}{*}{ BBNI } & \multirow{7}{*}{$\begin{array}{c}\text { Bank } \\
\text { Negara } \\
\text { Indooesia }\end{array}$} & 2010 & $4,23 \%$ & 2 & Stbat \\
\hline & & & 2011 & $3,61 \%$ & 2 & Sebat \\
\hline & & & 2012 & $2,35 \%$ & 2 & Stbat \\
\hline & & & 2013 & $2,20 \%$ & 2 & Sthat \\
\hline & & & 2014 & $2,00 \%$ & 2 & Selat \\
\hline & & & 2015 & $2,70 \%$ & 2 & Sebat \\
\hline & & & 2016 & $3,00 \%$ & 2 & Sthat \\
\hline \multirow{7}{*}{3} & \multirow{7}{*}{ BBTN } & \multirow{7}{*}{$\begin{array}{c}\text { Bade } \\
\text { Tabrogan } \\
\text { Nezara }\end{array}$} & 2010 & $3,26 \%$ & 2 & Stbat \\
\hline & & & 2011 & $2,73 \%$ & 2 & Sebat \\
\hline & & & 2012 & $4,09 \%$ & 2 & Sebat \\
\hline & & & 2013 & $4,03 \%$ & 2 & Sebat \\
\hline & & & 2014 & $4,01 \%$ & 2 & Sebat \\
\hline & & & 2015 & $3,42 \%$ & 2 & Sthat \\
\hline & & & 2016 & $2,34 \%$ & 2 & Selat \\
\hline
\end{tabular}


Tabel 8.

Analisis Profil Risiko Risiko Likuiditas (Loan to Deposit Ratio-LDR)

\begin{tabular}{|c|c|c|c|c|c|c|}
\hline No. & $\begin{array}{l}\text { Rode } \\
\text { Sabsm }\end{array}$ & $\begin{array}{c}\text { Nama } \\
\text { Perusabasa }\end{array}$ & Talrua & LDR & $\begin{array}{c}\text { Iodels } \\
\text { Komposit }\end{array}$ & Predlat \\
\hline \multirow{7}{*}{1} & \multirow{7}{*}{ BBCA } & \multirow{7}{*}{$\begin{array}{l}\text { Bant: } \\
\text { Cestral } \\
\text { Asia }\end{array}$} & 2010 & $35,20 \%$ & 1 & Sanzat Sabat \\
\hline & & & 2011 & $61,70 \%$ & 1 & Sungat Sebat \\
\hline & & & 2012 & $65,60 \%$ & 1 & Sungat Sebat \\
\hline & & & 2013 & $73,40 \%$ & 2 & Selast \\
\hline & & & 2014 & $76,90 \%$ & 2 & Sabat \\
\hline & & & 2015 & $31,10 \%$ & 2 & Sebat \\
\hline & & & 2016 & $7,10 \%$ & 2 & Sebat \\
\hline \multirow{7}{*}{2} & \multirow{7}{*}{ BBRI } & \multirow{7}{*}{$\begin{array}{c}\text { Bant: } \\
\text { Rakyat } \\
\text { Indocesia }\end{array}$} & 2010 & $73,17 \%$ & 2 & Sebat \\
\hline & & & 2011 & $76,20 \%$ & 2 & Sthat \\
\hline & & & 2012 & $99,35 \%$ & 2 & Sebat \\
\hline & & & 2013 & 85,54\% & 3 & Colsop Sebat \\
\hline & & & 2014 & $31,65 \%$ & 2 & Sthat \\
\hline & & & 2015 & $36,53 \%$ & 3 & Culexp Sebat \\
\hline & & & 2016 & $37,70 \%$ & 3 & Culexp Sebst \\
\hline \multirow{7}{*}{3} & \multirow{7}{*}{ BMRI } & \multirow{7}{*}{$\begin{array}{l}\text { Bank } \\
\text { Maodiri }\end{array}$} & 2010 & $65,44 \%$ & 1 & Sangat Sthat \\
\hline & & & 2011 & $71,63 \%$ & 1 & Sungat Sthat \\
\hline & & & 2012 & $77,66 \%$ & 2 & Sebat \\
\hline & & & 2013 & $329 \%$ & 2 & Sebat \\
\hline & & & 2014 & $32,0 \%$ & 2 & Sebat \\
\hline & & & 2015 & $37,05 \%$ & 3 & Culapp Sebst \\
\hline & & & 2016 & $35,36 \%$ & 3 & Colesp Sabst \\
\hline \multirow{7}{*}{4} & \multirow{7}{*}{ BBNI } & \multirow{7}{*}{$\begin{array}{c}\text { Bant: } \\
\text { Nezara } \\
\text { Indooesia }\end{array}$} & 2010 & $70,15 \%$ & 1 & Sungat Schat \\
\hline & & & 2011 & $70,37 \%$ & 1 & Sungat Schat \\
\hline & & & 2012 & $n, 50 \%$ & 2 & Sebat \\
\hline & & & 2013 & $35,30 \%$ & 3 & Odesp Sebat \\
\hline & & & 2014 & $37,50 \%$ & 3 & Colvep Sebat \\
\hline & & & 2015 & $37,90 \%$ & 3 & Odasp Sthat \\
\hline & & & 2016 & $90,40 \%$ & 3 & Oulap Sthat \\
\hline \multirow{7}{*}{5} & \multirow{7}{*}{ BBTN } & \multirow{7}{*}{$\begin{array}{c}\text { Banl: } \\
\text { Tabragan } \\
\text { Negara }\end{array}$} & 2010 & $100,42 \%$ & 4 & Rrang Sehat \\
\hline & & & 2011 & $10256 \%$ & 4 & Brang Sehat \\
\hline & & & 2012 & $100,90 \%$ & 4 & Rruang Sebat \\
\hline & & & 2013 & $104,20 \%$ & 4 & Rrang Sebat \\
\hline & & & 2014 & $105,56 \%$ & 4 & Rrang Sthat \\
\hline & & & 2015 & $105,73 \%$ & 4 & Krang Sehat \\
\hline & & & 2016 & $102,66 \%$ & 4 & Burang Sebat \\
\hline
\end{tabular}

Tabel 9

Analisis Good Corporate Governance (GCG)

\begin{tabular}{|c|c|c|c|c|c|c|}
\hline No. & $\begin{array}{l}\text { Kode } \\
\text { Sabsm }\end{array}$ & $\begin{array}{c}\text { Nama } \\
\text { Perosabasa }\end{array}$ & Tahroa & GCG & $\begin{array}{c}\text { Indeles } \\
\text { Komposit }\end{array}$ & Predicat \\
\hline \multirow{7}{*}{1} & \multirow{7}{*}{ BBCA } & \multirow{7}{*}{$\begin{array}{l}\text { Band } \\
\text { Central } \\
\text { Asia }\end{array}$} & 2010 & 1,35 & 1 & Sanzat BaX \\
\hline & & & 2011 & 1,00 & 1 & Sanzat Bax \\
\hline & & & 2012 & 1,08 & 1 & Sunzat Bs\% \\
\hline & & & 2013 & 1,00 & 1 & Sanzat Baz: \\
\hline & & & 2014 & 1,00 & 1 & Sanzat Baz \\
\hline & & & 2015 & 1,00 & 1 & Sanzat Baz: \\
\hline & & & 2016 & 1,00 & 1 & Sanza: Bax \\
\hline \multirow{7}{*}{2} & \multirow{7}{*}{ BBRI } & \multirow{7}{*}{$\begin{array}{c}\text { Bank } \\
\text { Rakyat } \\
\text { Indoosia }\end{array}$} & 2010 & 1,45 & 1 & Sangat Baz \\
\hline & & & 2011 & 1,30 & 1 & Sanzat Baz \\
\hline & & & 2012 & 1,30 & 1 & Sanzat Bax \\
\hline & & & 2013 & 1,29 & 1 & Sanzat Baz \\
\hline & & & 2014 & 1,12 & 1 & Sanzat Baz \\
\hline & & & 2015 & 1,17 & 1 & Sangat Baz \\
\hline & & & 2016 & 2,00 & 2 & $\mathrm{Bs}$. \\
\hline \multirow{7}{*}{3} & \multirow{7}{*}{ BMRI } & \multirow{7}{*}{$\underset{\text { Mandiri }}{\text { Bank }}$} & 2010 & 1,10 & 1 & Tidak Baz \\
\hline & & & 2011 & 1,00 & 1 & Sanza: BaX \\
\hline & & & 2012 & 1,50 & 2 & $\mathrm{Bs} z$ \\
\hline & & & 2013 & 2,00 & 2 & $\mathrm{Baz}$ \\
\hline & & & 2014 & 2,00 & 2 & $\mathrm{Baz}$ \\
\hline & & & 2015 & 2,00 & 2 & Baz: \\
\hline & & & 2016 & 2,00 & 2 & Bax \\
\hline \multirow{7}{*}{4} & \multirow{7}{*}{ BBNI } & \multirow{7}{*}{$\begin{array}{c}\text { Bank } \\
\text { Nezara } \\
\text { Indooesia }\end{array}$} & 2010 & 1,40 & 1 & Sanzat Baz \\
\hline & & & 2011 & 1,25 & 1 & Sanzat Bax \\
\hline & & & 2012 & 1,30 & 1 & Sanzat Baz \\
\hline & & & 2013 & 2,00 & 2 & Baz \\
\hline & & & 2014 & 2,00 & 2 & Bsy \\
\hline & & & 2015 & 2,00 & 2 & $\mathrm{Baz}$ \\
\hline & & & 2016 & 2,00 & 2 & Baz \\
\hline \multirow{7}{*}{5} & \multirow{7}{*}{ BBTN } & \multirow{7}{*}{$\begin{array}{c}\text { Bank } \\
\text { Tabuagan } \\
\text { Negara }\end{array}$} & 2010 & 1,23 & 1 & Sanzat Baz \\
\hline & & & 2011 & 1,15 & 1 & Sanzat Bax \\
\hline & & & 2012 & 1,35 & 1 & Sanzat Bay \\
\hline & & & 2013 & 3,00 & 3 & 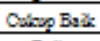 \\
\hline & & & 2014 & 2,00 & 2 & $\mathrm{Baz}$ \\
\hline & & & 2015 & 2,00 & 2 & Baz: \\
\hline & & & 2016 & 2,00 & 2 & Bax \\
\hline
\end{tabular}


Tabel 10

Analisis Rentabilitas (Return on AssetsROA)

\begin{tabular}{|c|c|c|c|c|c|c|}
\hline No. & $\begin{array}{l}\text { Kode } \\
\text { Sabam }\end{array}$ & $\begin{array}{c}\text { Nama } \\
\text { Perosabasa }\end{array}$ & Takroa & $R O A$ & $\begin{array}{c}\text { Indelss } \\
\text { Komposit }\end{array}$ & Predicat \\
\hline \multirow{7}{*}{1} & \multirow{7}{*}{ BBCA } & \multirow{7}{*}{$\begin{array}{l}\text { Bant: } \\
\text { Cearal } \\
\text { Asia }\end{array}$} & 2010 & $3,50 \%$ & 1 & Sanzat Sebat \\
\hline & & & 2011 & $3,90 \%$ & 1 & Sangat Sebat \\
\hline & & & 2012 & $3,60 \%$ & 1 & Sangat Sehat \\
\hline & & & 2013 & $3,50 \%$ & 1 & Sangat Sehat \\
\hline & & & 2014 & $3,90 \%$ & 1 & Sangat Sabat \\
\hline & & & 2015 & $3,50 \%$ & 1 & Sangat Sehat \\
\hline & & & 2016 & $4,00 \%$ & 1 & Sangat Sebat \\
\hline \multirow{7}{*}{2} & \multirow{7}{*}{ BBRI } & \multirow{7}{*}{$\begin{array}{c}\text { Bank } \\
\text { Ralizyat } \\
\text { Indoossia }\end{array}$} & 2010 & $4,64 \%$ & 1 & Sanzat Sebat \\
\hline & & & 2011 & $4,95 \%$ & 1 & Sanzat Sebat \\
\hline & & & 2012 & $3,15 \%$ & 1 & Sanzat Sehat \\
\hline & & & 2013 & $3,05 \%$ & 1 & Sanzat Sehat \\
\hline & & & 2014 & $4,75 \%$ & 1 & Sanzat Sebat \\
\hline & & & 2015 & $4,19 \%$ & 1 & Sunzat Sthat \\
\hline & & & 2016 & $3,54 \%$ & 1 & Sangat Sebat \\
\hline \multirow{7}{*}{3} & \multirow{7}{*}{ BMRI } & \multirow{7}{*}{$\begin{array}{c}\text { Bant } \\
\text { Maodiri }\end{array}$} & 2010 & $3,50 \%$ & 1 & Sanzat Sebat \\
\hline & & & 2011 & $3,37 \%$ & 1 & Sanzat Sebat \\
\hline & & & 2012 & $3,55 \%$ & 1 & Sanzat Sehat \\
\hline & & & 2013 & $3,65 \%$ & 1 & Sanzat Sehat \\
\hline & & & 2014 & $3,57 \%$ & 1 & Sanzat Sebat \\
\hline & & & 2015 & $3,15 \%$ & 1 & Sunzat Sehat \\
\hline & & & 2016 & $1,95 \%$ & 2 & Schat \\
\hline \multirow{7}{*}{4} & \multirow{7}{*}{ BBNI } & \multirow{7}{*}{$\begin{array}{c}\text { Bank } \\
\text { Nezara } \\
\text { Indooesia }\end{array}$} & 2010 & $2,49 \%$ & 1 & Sanzat Sebat \\
\hline & & & 2011 & $2,94 \%$ & 1 & Sangat Sehat \\
\hline & & & 2012 & $2,90 \%$ & 1 & Sanzat Sabat \\
\hline & & & 2013 & $3,40 \%$ & 1 & Sanzat Sebat \\
\hline & & & 2014 & $3,50 \%$ & 1 & Sanzat Sebat \\
\hline & & & 2015 & $2,60 \%$ & 1 & Sanzat Sebat \\
\hline & & & 2016 & $2,70 \%$ & 1 & Sanzat Sebat \\
\hline \multirow{7}{*}{5} & \multirow{7}{*}{ BBTN } & \multirow{7}{*}{$\begin{array}{c}\text { Bank } \\
\text { Tabragan } \\
\text { Negara }\end{array}$} & 2010 & $2,05 \%$ & 1 & Sanzat Sebat \\
\hline & & & 2011 & $2,05 \%$ & 1 & Sangat Sehat \\
\hline & & & 2012 & $1,94 \%$ & 2 & Sethat \\
\hline & & & 2013 & $1,79 \%$ & 2 & Sehat \\
\hline & & & 2014 & $1,14 \%$ & 3 & Culang Sehat \\
\hline & & & 2015 & $1,61 \%$ & 2 & Sebat \\
\hline & & & 2016 & $1,76 \%$ & 2 & Sabat \\
\hline
\end{tabular}

Tabel 11

Analisis Rentabilitas (Net Interest Margin-NIM)

\begin{tabular}{|c|c|c|c|c|c|c|}
\hline No. & $\begin{array}{l}\text { Rode } \\
\text { Sabam }\end{array}$ & $\begin{array}{c}\text { Nama } \\
\text { Perusabasa }\end{array}$ & Tahrea & NTM & $\begin{array}{c}\text { Iodelss } \\
\text { Komposit }\end{array}$ & Predicat \\
\hline \multirow{7}{*}{1} & \multirow{7}{*}{ BBCA } & \multirow{7}{*}{$\begin{array}{l}\text { Bunk } \\
\text { Censal } \\
\text { Asia }\end{array}$} & 2010 & $3,30 \%$ & 1 & Sangat Sehat \\
\hline & & & 2011 & $3,70 \%$ & 1 & Sangat Sebat \\
\hline & & & 2012 & $3,60 \%$ & 1 & Sangat Sebat \\
\hline & & & 2013 & $6,20 \%$ & 1 & Sangat Sthat \\
\hline & & & 2014 & $6,50 \%$ & 1 & Sangat Sebat \\
\hline & & & 2015 & $6,70 \%$ & 1 & Sangat Sehat \\
\hline & & & 2016 & $6,50 \%$ & 1 & Sungat Sebat \\
\hline \multirow{7}{*}{2} & \multirow{7}{*}{ BBRI } & \multirow{7}{*}{$\begin{array}{c}\text { Bank } \\
\text { Rakyat } \\
\text { Indooesia }\end{array}$} & 2010 & $10,7 \%$ & 1 & Sangat Sthat \\
\hline & & & 2011 & $9,53 \%$ & 1 & Sungat Sehat \\
\hline & & & 2012 & $3,42 \%$ & 1 & Sanzat Sebat \\
\hline & & & 2013 & $8,53 \%$ & 1 & Sanzat Sehat \\
\hline & & & 2014 & $851 \%$ & 1 & Sanzat Sebat \\
\hline & & & 2015 & $8,13 \%$ & 1 & Sugzat Sebat \\
\hline & & & 2016 & $8,27 \%$ & 1 & Sanzat Sebat \\
\hline \multirow{7}{*}{3} & \multirow{7}{*}{ BMaRI } & \multirow{7}{*}{$\begin{array}{c}\text { Bank } \\
\text { Mandiri }\end{array}$} & 2010 & $3,39 \%$ & 1 & Sunzat Sebat \\
\hline & & & 2011 & $3,29 \%$ & 1 & Sangat Sebat \\
\hline & & & 2012 & $3,53 \%$ & 1 & Sxnzat Sthat \\
\hline & & & 2013 & $3,65 \%$ & 1 & Sangat Sebat \\
\hline & & & 2014 & $3,94 \%$ & 1 & Sanzat Sthat \\
\hline & & & 2015 & $3,90 \%$ & 1 & Sangat Sebat \\
\hline & & & 2016 & $6,29 \%$ & 1 & Sangat Sebat \\
\hline \multirow{7}{*}{4} & \multirow{7}{*}{ BBNI } & \multirow{7}{*}{$\begin{array}{c}\text { Bank } \\
\text { Nezara } \\
\text { Indooesia }\end{array}$} & 2010 & $3,73 \%$ & 1 & Sangat Stbat \\
\hline & & & 2011 & $6,03 \%$ & 1 & Sungat Sthat \\
\hline & & & 2012 & $3,90 \%$ & 1 & Sangat Sabat \\
\hline & & & 2013 & $6,10 \%$ & 1 & Sungat Sebat: \\
\hline & & & 2014 & $6,20 \%$ & 1 & Sangat Sebat \\
\hline & & & 2015 & $6,40 \%$ & 1 & Sanzat Sebat \\
\hline & & & 2016 & $6,20 \%$ & 1 & Sangat Sebat \\
\hline \multirow{7}{*}{5} & \multirow{7}{*}{ BBTN } & \multirow{7}{*}{$\begin{array}{c}\text { Bank } \\
\text { Tabuagan } \\
\text { Negara }\end{array}$} & 2010 & $3,9 \% \%$ & 1 & Sanzat Stbat \\
\hline & & & 2011 & $3,76 \%$ & 1 & Sangat Sthat \\
\hline & & & 2012 & $3,35 \%$ & 1 & Sangat Sthat \\
\hline & & & 2013 & $3,44 \%$ & 1 & Sanzat Sebat \\
\hline & & & 2014 & $4,47 \%$ & 1 & Sangat Sebat \\
\hline & & & 2015 & $4,37 \%$ & 1 & Sangat Sthat \\
\hline & & & 2016 & $4,95 \%$ & 1 & Sunzat Sabat \\
\hline
\end{tabular}


Tabel 12

Analisis Permodalan (Capital Adequacy Ratio-CAR)

\begin{tabular}{|c|c|c|c|c|c|c|}
\hline No. & $\begin{array}{l}\text { Kode } \\
\text { Saham }\end{array}$ & $\begin{array}{c}\text { Nama } \\
\text { Perusabaan }\end{array}$ & Tahroa & $\operatorname{CAR}$ & $\begin{array}{c}\text { Indeiss } \\
\text { Romposit }\end{array}$ & Predicat \\
\hline \multirow{7}{*}{1} & \multirow{7}{*}{ BBCA } & \multirow{7}{*}{$\begin{array}{l}\text { Bast: } \\
\text { Central } \\
\text { Asia }\end{array}$} & 2010 & $13,50 \%$ & 1 & Sanzat Sehat \\
\hline & & & 2011 & $12,70 \%$ & 1 & Sanzat Sehat \\
\hline & & & 2012 & $14,20 \%$ & 1 & Sanzat Sehat \\
\hline & & & 2013 & $15,70 \%$ & 1 & Sanzat Sabat \\
\hline & & & 2014 & $16,90 \%$ & 1 & Sanzat Sehat \\
\hline & & & 2015 & $18,70 \%$ & 1 & Sangat Sthat \\
\hline & & & 2016 & $21,90 \%$ & 1 & Sangat Sehat \\
\hline \multirow{7}{*}{2} & \multirow{7}{*}{ BBRI } & \multirow{7}{*}{$\begin{array}{c}\text { Bank } \\
\text { Rakyat } \\
\text { Indooesia }\end{array}$} & 2010 & $13,91 \%$ & 1 & Sanzat Sehat \\
\hline & & & 2011 & $14,99 \%$ & 1 & Sangat Sehat \\
\hline & & & 2012 & $16,95 \%$ & 1 & Sanzat Sehat \\
\hline & & & 2013 & $16,99 \%$ & 1 & Sanzat Sehat \\
\hline & & & 2014 & $18,31 \%$ & 1 & Sangat Sahat \\
\hline & & & 2015 & $20,59 \%$ & 1 & Sanzat Sebat \\
\hline & & & 2016 & $2291 \%$ & 1 & Sanzat Sehat \\
\hline \multirow{7}{*}{3} & \multirow{7}{*}{ BMIRI } & \multirow{7}{*}{$\begin{array}{c}\text { Bant } \\
\text { Masodiri }\end{array}$} & 2010 & $15,36 \%$ & 1 & Sanzat Sebat \\
\hline & & & 2011 & $13,34 \%$ & 1 & Sanzat Sehat \\
\hline & & & 2012 & $15,45 \%$ & 1 & Sanzat Sebat \\
\hline & & & 2013 & $14,95 \%$ & 1 & Sanzat Sehat \\
\hline & & & 2014 & $16,60 \%$ & 1 & Sangat Sthat \\
\hline & & & 2015 & $15,60 \%$ & 1 & Sanzat Sthat \\
\hline & & & 2016 & $21,35 \%$ & 1 & Sanzat Sebat \\
\hline \multirow{7}{*}{4} & \multirow{7}{*}{ BENI } & \multirow{7}{*}{$\begin{array}{c}\text { Bank } \\
\text { Negara } \\
\text { Iodooesia }\end{array}$} & 2010 & $18,65 \%$ & 1 & Sanzat Sabat \\
\hline & & & 2011 & $17,65 \%$ & 1 & Sangat Sehat \\
\hline & & & 2012 & $16,70 \%$ & 1 & Sanzat Sebat \\
\hline & & & 2013 & $15,10 \%$ & 1 & Sanzat Sehat \\
\hline & & & 2014 & $16,20 \%$ & 1 & Sanzat Sebat \\
\hline & & & 2015 & $1950 \%$ & 1 & Sanzat Sehat \\
\hline & & & 2016 & $19,40 \%$ & 1 & Sanzat Sthat \\
\hline \multirow{7}{*}{5} & \multirow{7}{*}{ BDTN } & \multirow{7}{*}{$\begin{array}{c}\text { Bank } \\
\text { Tabragan } \\
\text { Negara }\end{array}$} & 2010 & $16,74 \%$ & 1 & Sungat Sehat \\
\hline & & & 2011 & $15,03 \%$ & 1 & Sunzat Sebat \\
\hline & & & 2012 & $17,69 \%$ & 1 & Sangat Sthat \\
\hline & & & 2013 & $15,62 \%$ & 1 & Sanzat Sebat \\
\hline & & & 2014 & $14,64 \%$ & 1 & Sanzat Sahat \\
\hline & & & 2015 & $16,97 \%$ & 1 & Sanzat Sehat \\
\hline & & & 2016 & $20,34 \%$ & 1 & Sanzat Sehat \\
\hline
\end{tabular}

\section{Analisis Permodalan (Capital Adequacy Ratio-CAR)}

Dalam operasinya, perbankan diwajibkan untuk selalu memenuhi kecukupan modal minimum yang sudah dipersyaratkan. Kecukupan modal minimum ini berfungsi menampung kerugian apabila suatu risiko terjadi pada suatu bank. Pada situasi krisis, bank yang tidak memiliki modal yang cukup biasanya akan gagal bertahan terhadap kondisi tersebut. Hal ini disebabkan karena bank tidak dapat menanggung lagi kerugian yang ada selama periode krisis. Bank dengan modal yang cukup akan mampu bertahan karena untuk sementara waktu, kerugian yang diterima dapat ditutupi dengan modal yang ada.
Sehingga hanya sebagian kecil kegiatan operasi yang terganggu atau bahkan tidak terganggu sama sekali apabila memiliki modal yang sangat besar. Dalam hal ini, kecukupan modal suatu bank dihitung oleh CAR (Capital Adequacy Ratio) atau rasio kecukupan modal.

CAR yang dimiliki oleh seluruh perbankan yang ada dipenelitian ini berhasil memperoleh predikat "Sangat Sehat" (tabel 12). Predikat "Sangat Sehat" diberikan apabila suatu perbankan memiliki CAR di atas $12 \%$. CAR tertinggi pada penilitian ini dimiliki oleh Bank BRI yaitu pada tahun 2016 sebesar 22,91\%, sedangkan CAR terendah dimiliki oleh Bank BCA pada tahun 2011 sebesar 12,70\%. Dari hasil penelitian ini, dapat dikatakan bahwa perbankan yang termasuk Saham LQ45 memiliki kecukupan modal yang sangat sehat. Hal ini mengindikasikan bahwa perbankan memiliki kemungkinan yang cukup besar atau kemampuan yang kuat untuk bertahan pada kondisi-kondisi yang tidak normal atau krisis.

\section{Simpulan dan Saran}

\section{Simpulan}

Berdasarkan analisis kesehatan bank menggunakan metode Risk Based Bank Rating (RBBR) menggunakan rasio NPL, LDR, ROA, NIM, dan CAR serta publikasi hasil self-assesment GCG sebagai berikut:

1. Penilaian tingkat kesehatan bank yang dilihat melalui faktor profil risiko.

- Penilaian tingkat kesehatan bank yang dilihat melalui faktor profil risiko dengan rasio NPL menunjukkan bahwa seluruh perbankan dalam penelitian ini mampu memperoleh predikat "Sehat" dari tahun 2010 hingga 2016. Pada penelitian ini, Bank BCA merupakan satu-satunya bank yang memiliki predikat "Sangat Sehat" selama tahun 2010 hingga 2016. Sementara itu, Bank 
BNI dan BTN tidak memperoleh predikat "Sangat Sehat" dalam periode penelitian.

- Penilaian tingkat kesehatan bank yang dilihat melalui faktor profil risiko dengan rasio LDR menunjukkan bahwa Bank BCA berada pada posisi over liquid pada tahun 2010 hingga 2012. Hal tersebut dikarenakan Bank BCA memiliki rasio LDR yang sangat rendah, yaitu bernilai di bawah 70\%. Di samping itu, Bank BTN memperoleh predikat "Kurang Sehat" selama periode penelitian berlangsung. Hal ini menunjukkan bahwa Bank BTN berada pada posisi over lending dari tahun 2010 hingga 2016.

2. Penilaian tingkat kesehatan bank yang dilihat melalui faktor GCG

- Bank BCA memperoleh predikat "Sangat Baik" selama periode penelitian yaitu tahun 2010 hingga 2016. Selanjutnya, Bank BTN memperoleh predikat "Sangat Baik" pada tahun 2010 hingga 2012, predikat "Baik" pada tahun 2014 hingga 2016, dan predikat "Cukup Baik" pada tahun 2013. Sementara itu, bank-bank lainnya seperti Bank BRI, Mandiri, dan BNI memiliki predikat "Sangat Baik" dan juga "Baik" selama periode penelitian ini dilakukan.

3. Penilaian tingkat kesehatan bank yang dilihat melalui faktor rentabilitas

- Predikat "Sangat Sehat" hampir diperoleh oleh seluruh perbankan yang diteliti. Predikat "Cukup Sehat" diperoleh Bank BTN pada tahun 2014 dengan nilai sebesar 1,14\%. Rata-rata ROA tertinggi dimiliki oleh Bank BRI yaitu sebesar 4,64\% dan rata-rata ROA terendah dimiliki oleh Bank BTN yaitu sebesar $1,76 \%$.

- Pada penelitian ini, seluruh perbankan yang diteliti terkait dengan rasio NIM memperoleh predikat "Sangat Sehat". Rata-rata rasio NIM tertinggi dimiliki oleh Bank BRI yaitu $8,89 \%$ selama tahun 2010 hingga 2016. Sementara itu, Rata-rata rasio NIM terendah dimiliki oleh Bank BTN dengan nilai sebesar 5,33\%.

4. Penilaian tingkat kesehatan bank yang dilihat melalui faktor permodalan

- Seluruh perbankan yang diteliti memperoleh predikat "Sangat Sehat". Hal ini mencerminkan bahwa perbankan yang tergolong saham LQ45 memiliki memiliki kapasitas yang baik dalam bertahan pada kondisi-kondisi yang tidak normal atau krisis.

\section{Saran}

Dari hasil penelitian yang telah dilakukan, penulis hendak memberikan beberapa saran kepada pembaca seperti berikut:

1. Bagi Investor

Investor harus cermat dalam memilih perbankan yang akan diinvestasikan. Pemilihan perbankan dapat dilakukan dengan cara menilai atau menginterpretasikan hasil perhitungan rasio beserta predikat yang dimiliki suatu perbankan atas suatu rasio. Pemilihan perbankan yang tepat akan membawakan keuntungan pada investasi yang dilakukan.

2. Bagi Penelitian Selanjutnya

Bagi peneliti selanjutnya, disarankan untuk memperluas cakupan penelitian tentang penilaian kesehatan bank baik dengan menggunakan indikator rasio keuangan lainnya pada pengukuran tingkat kesehatan bank atau dengan memperbanyak sampel penelitian. 


\section{Daftar Pustaka}

Asnina, Siska Fitriya. 2016. Penilaian Kesehatan Bank dengan Pendekatan Risiko (Risk Based Bank Rating). Jurnal Ilmu dan Riset Akuntansi, 5 (8). pp 1-17.

Bank Indonesia. 2004. Surat Edaran Bank Indonesia Nomor. 6/ 23/ DPNP/2004 tentang Sistem Penilaian Tingkat Kesehatan Bank Umum. 31 Mei 2004.

Bank Indonesia. 2011. Surat Edaran Bank Indonesia Nomor. 13/ 24/ DPNP/2011 tentang Penilaian Tingkat Kesehatan Bank Umum. 25 Oktober 2011.

Peraturan Otoritas Jasa Keuangan Nomor 3 Tahun 2016 Tentang Penilaian Tingkat Kesehatan Bank Umum.

Sundjaja, Ridwan S., Inge Barlian, dan Dharma Putra Sundjaja. (2013). Manajemen Keuangan 1. Edisi 8. Bandung: Literata Lintas Media.

Susanti, Sandhy Dharmapermata. 2015 Analisis Tingkat Kesehatan Bank Dengan Menggunakan Metode Risk-Based Bank Rating (RBBR). Universitas Negeri Yogyakarta.

Undang-undang Nomor 10 Tahun 1998 tentang Perubahan Atas Undangundang Nomor 7 Tahun 1992 tentang Perbankan.

Widiyanto, Andi. 2015. Analisis Tingkat Kesehatan Bank dengan Menggunakan Metode Risk Based Bank Rating (RBBR) (Studi Pada Bank Yang Terdaftar di Bursa Efek Indonesia dalam IHSG Sub Sektor Perbankan Tahun 20122014).UniversitasDian

Nuswantoro Semarang. 